\title{
Tax Knowledge, Penalties and Tax Compliance in Small and Medium Scale Enterprises in Nigeria
}

\author{
Adesina Olugoke Oladipupo, Uyioghosa Obazee \\ Department of Accounting, Faculty of Management Sciences, University of Benin, Benin City, Nigeria \\ Email:sinaoladipupo@yahoo.com,sina.oladipupo@uniben.edu
}

Received 16 October 2015; accepted 28 February 2016; published 2 March 2016

Copyright (C) 2016 by authors and Scientific Research Publishing Inc.

This work is licensed under the Creative Commons Attribution International License (CC BY).

http://creativecommons.org/licenses/by/4.0/

(c) (i) Open Access

\begin{abstract}
The study investigated the impacts of tax payers' knowledge and penalties on tax compliance amongst small and medium enterprises in Nigeria using a survey research design. The data obtained from questionnaire were analyzed using the Ordinary Least Square regression method. The results showed that tax knowledge had a positive significant impact on tax compliance while tax penalty had insignificant positive impact on tax compliance. Thus, the study shows that tax knowledge has a higher tendency to promote tax compliance than tax penalty. Government should therefore do everything possible to increase public knowledge on tax matters and tax education should be included in school curricula at all times. Small and medium scale business owners should also seek to advance their tax knowledge and awareness for the mutual benefits of the governments and taxpayers.
\end{abstract}

\section{Keywords}

Tax Compliance, Tax Knowledge, Tax Penalty

\section{Introduction}

Taxes and tax system are essential in nation building. They are required for state capacity building for meaningful economic development [1]. The fundamental goal of any revenue authority is to collect taxes and duties payable according to the law. However, taxpayers are not always willing and ready to comply when it comes to the obligations imposed on them by law. Tax compliance is the ability and willingness of taxpayers to comply with tax laws, declare the correct incomes in each year and pay the right amount of taxes on time [2]. Reference [3] considered tax compliance as the taxpayers' willingness to obey tax laws in order to attain economic development and goal. From a wider perspective, tax compliance requires a degree of honesty, adequate tax know- 
ledge and capability to use this knowledge, timeliness, accuracy, and adequate records in order to complete the tax returns and associated tax documentation [4].

A key component of any tax system is the manner in which it is administered. No tax is better than its administration, so tax administration matters a lot [5]. An essential objective of tax administration is to ensure the maximum possible compliance by taxpayers of all types with their tax obligations. Unfortunately, in many developing countries, tax administration is usually weak and characterized by extensive evasion, corruption and coercion. In many cases, overall tax compliance levels are low and large proportion of the informal sector of the economy escapes the tax net entirely [1]

Tax compliance is a major problem for many tax authorities. It is not an easy task to persuade taxpayers to comply with tax requirements even as the tax laws are not always precise in some respects [6]. Taxpayers are inherently disposed to reducing their tax liability either through tax evasion or tax avoidance. This may give rise to incorrect filling of their tax returns and loss of revenue to the government. An unduly complex regulatory system and tax regime enforcement makes tax compliance unduly burdensome and often have a distortionary effect on the development of small and medium scale enterprises (SMEs) as they are tempted to change into forms that offer a lower tax burden or no tax burden at all [7], and as such results in a tax system that imposes high expenses on the society. A poorly executed tax system also leads to low efficiency, high collection charges, and waste of time for taxpayers [8]. SMEs usually have to operate in an overbearing regulatory environment with the plethora of regulatory agencies, multiple taxes, cumbersome importation procedure and high port charges that constantly exert serious burden on their operations [9]. Existing empirical evidence clearly indicates that small and medium sized businesses are affected disproportionately by these costs when scaled by sales or assets. The compliance costs of SMEs are higher than the larger businesses [10].

This leads to limited capacity of developing countries to raise revenues for development purposes. A lot of factors affect the low level of tax compliance in developing countries, such as attitudes, penalty, income, education, knowledge, gender and age of the taxpayers, corruption, high marginal tax rates, lack of availability of information and accounting systems, a large informal sector, weak regulatory systems, ambiguity in the tax law, the existence of non adherent culture, and the ineffectiveness of tax administration [6].

The objectives of this paper therefore are to assess the degree of compliance of the relevant tax laws by taxpayers and find out the effects of tax knowledge and tax penalty over tax compliance. The rest of the paper is divided into four parts. Beside this introduction, Section two is a review of literature while Section three is on methodology. Section four presents the results and discussion while the last section is on summary and conclusion.

\section{Literature Review}

We present a review of literature on two factors influencing tax compliance below. These are tax knowledge and tax penalty.

\subsection{Tax Knowledge}

Tax knowledge is the level of awareness or sensitivity of the taxpayers to tax legislation. Tax knowledge refers to the processes, by which taxpayers become aware of tax legislation and other tax-related information [11]. The level of formal general education received by taxpayers is an important factor that contributes to the understanding of tax requirements, especially regarding registration and filling requirements. Generally, citizens have very limited knowledge on government true expenditures and the cost of public services provided by the government [12]. Hence, those taxpayers without tax knowledge are compelled to solicit the service of tax professionals [13] [14]. One of the fundamental ways to increase public awareness is for taxpayers to have knowledge about taxation [15] [16]. Reference [17] observes that general education level is significantly related to tax evasion.

High awareness by the society would encourage people to fulfill their obligations to register as taxpayer reporting and paying taxes properly are forms of national and civic responsibility. Most citizens do not have much understanding of what tax laws mean and why the tax system is structured and administered as it is [18]. Reference [19] states that tax knowledge reveal that there is a relationship with taxpayers' ability to understand the laws and regulation of taxation and their ability to comply. In this study, SMEs did not consider local authority levies to be different from government taxes because they lacked tax knowledge. This misconception has an impact on their compliance decision because when they pay council levies they might consider that they have 
paid tax and complied. Reference [9] found that SMEs did not pay their tax obligations because of their inability to understand tax law requirements.

Increase awareness and knowledge of a tax initiative is essential to gain public acceptance and confidence [16]. Awareness has to be spread in order to inform all consumers about the direction and objectives the authorities wish to achieve by administering taxation policy [20]. References [21] [22] conclude that tax knowledge has a significant impact on tax compliance in meeting their tax obligations. Similarly, Reference [23] also opines that knowledge of taxation can affect the perceived fairness of tax by the taxpayers. For taxpayers to accurately compute his tax liability reasonable tax knowledge is required [24].

From the foregoing, it is observed that previous studies have evidenced that tax knowledge play an important role in increasing tax compliance. Tax knowledge could potentially encourage taxpayers to be more prudent in completing their tax returns. Hence, we hypothesized that there is a significant relationship between tax knowledge and tax compliance.

\subsection{Tax Penalty}

Tax penalty is a punitive measure that the tax law imposes for the performance of an act that is proscribed, or for the failure to perform a required act such as failure to timely file return or filling wrong or undervalued returns etc. If a taxpayer is required to file an income or excise tax return and fails to timely do so, a late filing penalty may be assessed. The penalty is $5 \%$ of the amount of unpaid tax per month (or partial month) the return is late, up to a maximum of 25\% (Legal Dictionary). How does tax penalty imposable on taxpayers for noncompliance can promote tax compliance amongst taxpayers?

Deterrence factors such as probability of being audited and being detected by tax authorities are found to reduce noncompliance among taxpayers [25] [26]. For instance, Nigeria Personal Income Tax Act (PITA 2011 as amended) strengthen such issues as record keeping, self-assessment and provides penalty of $\$ 50,000$ and $\$ 500,000$ for individuals and companies respectively for contravening the provisions of the Act [27]. Furthermore, under self-assessment in Nigeria the failure of taxpayer to file returns will make him liable upon conviction to pay a sum of $\$ 200$ and further $\$ 40$ for everyday during which the failure continues [28]. In Malaysia, if it is discovered during the audit process that there is underreporting or misstatement, a penalty will be imposed under subsection 113(2) of the ITA (1967), although revenue authorities in Malaysia encourage taxpayers who underreport their income to voluntarily make disclosure of such underreporting if later they understand that they made underreporting of their income. Failure to do so is subject to penalty depending on the time that has lapsed between omission and voluntary disclosure [29].

Reference [25] introduced a theoretical economic model that indicates that penalties have an impact on tax compliance. There have been mixed results on the effect of tax penalties on tax compliance. Reference [30] observed that penalty rates had a positive association with tax evasion, meaning that higher rates would encourage people to cheat. Reference [31] examined the effect of fines and penalties on tax compliance among small and medium enterprises. The study shows a positive effect of fines and penalties on tax compliance. However, some studies suggest that an increase of penalties can have undesirable effect and result in more tax avoidance [32]. The higher the penalty the greater the discouragement for potential tax evasion. On the one hand, fines should be high enough to decrease the expected value of tax evasion and to assure its deterrent effect on tax payers. References [33]-[35] found that penalty rates have negative association with tax evasion. References [34] [36] [37] also found that tax penalty rates have a negative association with tax compliance. Thus, there is no conclusion on the effect of tax penalties on tax compliance. Hence, we hypothesize that there is no significant relationship between tax penalties and tax compliance.

\subsection{Theories on Tax Compliance}

There are various opinions as to the best ways to improve tax compliance. Given the opportunity, a lot of businesses will not pay taxes unless there is a motivation to do so. Some believe that the best way is to increase tax incentives [38] while others believe that the best way is to increase tax penalties. Thus, tax compliance theories are broadly classified into two. They are the deterrence based theory and psychology based theory.

\subsubsection{Deterrence Theory}

This theory places emphasis on incentives. The theory suggests that taxpayers are amoral utility maximizers 
who are influenced by economic motives such as profit maximization and probability of detection. Hence, the taxpayers analyze alternative compliance paths for instance whether or not to evade tax, the likelihood of being detected and the resulting repercussions and then select the alternative way that maximizes their expected after tax returns after adjusting for risk. Therefore according to the theory, in order to improve compliance, penalties for non-compliance should be increased. Thus, there is a theoretical positive relationship between tax penalty and tax compliance. Increase in tax penalty would lead to increase in tax compliance and vice versa.

\subsubsection{Psychology Theory}

Psychology theory posits that taxpayers are influenced to comply with their tax obligations by psychological factors. It focuses on the taxpayers' morals and ethics. The theory suggests that a taxpayer may comply even when the probability of detection is low. As opposed to the deterrence theory that emphasizes increased penalty as solution to compliance issues, psychology theory lays emphasis on changing individual attitudes towards tax systems. Thus, one instrument of changing taxpayers' attitude to tax matters is tax education. It is assumed that improved tax education would increase tax compliance and vice versa.

\section{Methodology}

This section presents the model specification for the study and methods of data collection and analysis.

\subsection{Model Specification}

In the earlier study on tax compliance in Nigeria, [39] expressed attitude of taxpayer towards tax compliance (ATTCOM) as a function of tax morale (TMOR). The functional relationship is shown in Equation (1).

$$
\mathrm{ATTCOM}=\mathrm{TMOR}+\varepsilon
$$

However, tax morale (TMOR) was expressed as a function of social norms (SON), attitude of taxpayers towards government (ATG), tax evasion (ATTEV), tax avoidance (ATTAV), legal system (ATLS), and obedience to traditional institution (OTTI). This was expressed as shown in Equation (2) below.

$$
\mathrm{TMOR}=\alpha_{\mathrm{O}}+\beta_{1} \mathrm{SON}+\beta_{2} \mathrm{ATG}+\beta_{3} \mathrm{ATTEV}+\beta_{4} \mathrm{ATTAV}+\beta_{5} \mathrm{ATLS}+\beta_{6} \mathrm{OTTI}+\varepsilon
$$

However, in this study we opined that the attitude of taxpayers towards tax compliance (TCOMP) depends on the knowledge of taxpayers on tax matters (TKNOW) and the amount of tax penalty levied on taxpayers for noncompliance (TPEN). This model is therefore expressed as shown in Equation (3).

$$
\text { TCOMP }=\alpha_{0}+\text { TKNOW } \beta_{1}+\text { TPEN } \beta_{2}+\varepsilon
$$

where:

$$
\begin{aligned}
& \text { TCOMP }=\text { Tax compliance, } \\
& \text { TKNOW = Tax knowledge, } \\
& \text { TPEN = Tax penalties, } \\
& \varepsilon=\text { The error term. }
\end{aligned}
$$

\subsection{Methods of Data Collection and Analysis}

The research design adopted in this study is survey design. The primary source of data employed is the administration of questionnaires. The questionnaire consists of two parts. The part A of the questionnaire is on the demographic characteristics of the respondents while part $\mathrm{B}$ of the questionnaire is on the research questions on the research variables namely, tax compliance, tax knowledge and tax penalty. Five-point Likert-style rating scale method of questionnaire was employed in this study ranging from strongly agree of 5-point to strongly disagree of 1-point. The Likert -style rating method of questionnaire design enables numerical value to be assigned to cases for easy quantitative analysis. To test for the content validity of the instrument used for data collection in this study, the questionnaire was given to three experts in the Departments of Accounting, Business Administration and Sociology of University of Benin for review. To ensure the reliability of the instrument, the questionnaire was pre-tested using twenty (20) respondents. Using Statistical Package for Social Sciences (SPSS) to test the reliability, the Cronbach alpha coefficient of 0.82 was obtained. This compares favourably with a stipulated 
standard of above 0.70 for reliability test. The reliability ratio for this work $(0.82)$ showed that all the research questions in the questionnaire have internal consistency.

The small and medium enterprises in Benin City in Edo state, Nigeria constitute the population of the study. A total of four hundred respondents were randomly sampled from small and medium enterprises in Benin City in Edo state, Nigeria. Out of the four hundred (400) questionnaires administered to SME operators, two hundred and seventy seven (277) were retrieved and analyzed. The data obtained were analysed using Statistical Package for Social Sciences (SPSS) to obtain the frequency distributions of the demographic characteristics of the respondents. The descriptive statistics of the variables as well as the Ordinary Least Square (OLS) multiple regression analysis was carried out to assess the relative predictive power of the independent variables (i.e. tax knowledge and tax penalty) on the dependent variable (i.e. tax compliance).

\section{Results and Discussion}

The results of the data analysis in this study are presented and discussed in this section. The section contains three parts. The first part describes the frequency distribution of three demographic characteristics of the respondents in this study. The second part presents the results of the descriptive statistical analysis of the research variables of tax compliance, tax knowledge and tax penalty under study. The last part is the result of regression analysis.

\subsection{Demographic Characteristics of the Respondents}

Four demographic characteristics of the respondents were considered in this study. These are the gender, age, education, and annual income. Majority of the respondents were male (198\% or $71 \%$ ) while the rest were female (79\% or $29 \%$ ). The reason could be far from the fact that many business operators in SMEs are male as many females before now are more into business of home managers. Most of the respondents (54\%) were above 40 years of age. Table 1 shows the age distribution of the respondents.

Again, the majority of the respondents had first degree certificate and above (71.5\%) while few had just secondary school certificate (28.5\%). Table 2 shows details. The implication is that majority of the respondents had general education. Does level of general education translate or fix a person with tax knowledge? This may not be so. It is tax education that fixes a person with tax knowledge. However, general education may predispose a person to tax education with its concomitant tax knowledge.

The annual income of the respondents spans from below N200,000 to over N500,000. However, majority of the respondents have annual income within the bracket of N200,000 - N500,000. Table 3 shows the details.

\begin{tabular}{ccc} 
Table 1. Age distribution of respondents. & \\
\hline Class & Freq. & $\%$ \\
\hline Below 31 years & 43 & 15.5 \\
31 - 40 years & 85 & 30.7 \\
41 - 50 years & 96 & 34.7 \\
Above 50 years & 53 & 19.1 \\
Total & 277 & 100.0 \\
\hline
\end{tabular}

Source: Authors (2015).

Table 2. Education distribution of respondents.

\begin{tabular}{ccc}
\hline Class & Freq. & $\%$ \\
SSCE & 79 & 28.5 \\
B.Sc. & 128 & 46.2 \\
Masters & 70 & 25.3 \\
Total & 277 & 100.0 \\
\hline
\end{tabular}

Source: Authors (2015). 
Table 3. Annual income distribution of respondents.

\begin{tabular}{ccc}
\hline Class & Freq. & $\%$ \\
\hline Below $\mathrm{N} 200,000$ & 98 & 35.4 \\
Between $\$ 200,000-\$ 500,000$ & 108 & 39.0 \\
Above N500,000 & 71 & 25.6 \\
Total & 277 & 100.0 \\
\hline
\end{tabular}

Source: Authors (2015).

\subsection{Descriptive Statistics of the Research Variables}

Table 4 shows the descriptive statistics of the research variables under study, namely; tax compliance (TCOMP), tax knowledge (TKNOW) and tax penalty (TPEN). The minimum value of TCOMP is 2 while the maximum value of TCOMP is about 5 . The average of the TCOMP is about 4.18. The minimum TKNOW is about 2 while the maximum TKNOW is about 5. On average the TKNOW is about 4.16. The minimum TPEN is about 1.667 while the maximum TPEN is about 5 . On average the TPEN is about 4.30. The high values of Jacque-Bera statistics with their probability values of $<0.05$ revealed that all the variables are normally distributed.

Table 5 presents the results of the Pearson's Product Moment correlation analysis. The results show significant positive relationships between tax compliance (TCOMP) and tax knowledge (TKNOW) and between tax compliance (TCOMP) and tax penalty (TPEN). However, there is no strong significant relationship between tax knowledge (TKNOW) and tax penalty (TPEN). This shows absence of possible multicolinearity between the two independent variables (TKNOW and TPEN).

The results of regression analysis are presented in Table 6 . The two independent variables are properly signed in that both have positive effects on tax compliance. These conformed to their a-priori positive sign that indicates that increase in tax knowledge and tax penalty would lead to increase in tax compliance amongst taxpayers and vice versa. However, a unit increase in tax knowledge would lead to 0.46 increase in tax compliance while a unit increase in tax penalty would lead to 0.12 increase in tax compliance. Thus, tax knowledge has a higher tendency to promote tax compliance than tax penalty. In terms of significance, only the tax knowledge has significant effect on tax compliance at $5 \%$ level of significance. Tax penalty does not have significant effect on tax compliance at 5\% level of significance. However, both the tax knowledge (TKNOW) and tax penalty (TPEN) could only explain about $31 \%$ of the systematic variations in tax compliance while about $69 \%$ of the systematic variations in tax compliance could not be accounted for by the regression model. However, the model passes the test of goodness of fit given the value of F-statistics of 63.41589 with its associated probability (prob. $<0.05$ ). The Durbin-Watson statistic of 1.797772 shows an absence of auto-correlation, which is not a serious issue in a cross-sectional study like ours.

From the foregoing it is observed that tax knowledge (TKNOW) has significant positive relationship with tax compliance (TCOMP). The finding is consistent with the study of [20] that opined that tax awareness has to be spread in order to inform all consumers about the direction and objectives the relevant tax authorities wish to achieve by administering taxation policy. However, tax penalty has insignificant positive impact on tax compliance. This is inconsonance with the studies of [30] [31] who observed that tax penalty rates had significant positive association with tax evasion, meaning that higher tax penalty rates did indeed encourage people to cheat or avoid tax.

\section{Summary and Conclusions}

An attempt has been made in this paper to present an in-depth analysis of the effects of tax knowledge and tax penalties on tax compliance amongst small and medium enterprises in Nigeria. The study shows that tax knowledge has a higher tendency to promote tax compliance than tax penalty. Tax knowledge plays an important role in increasing tax compliance. Tax knowledge could potentially encourage tax payers to be more prudent in completing their tax returns. Self-employed individuals should try as much as possible to acquire reasonable level of tax knowledge as it applies to their businesses. Acquiring tax knowledge has many advantages. It would save the tax payers from hiring consultants to compute taxes for their businesses and thereby saving huge tax consultancy cost. It can assist them to accurately compute tax payable and avoid unintentional noncompliance 
Table 4. Descriptive statistics on the variables.

\begin{tabular}{cccc}
\hline & TCOMP & TKNOW & TPEN \\
\hline Mean & 4.182671 & 4.163899 & 4.305656 \\
Median & 4.2 & 4.2 & 4.333333 \\
Maximum & 5 & 5 & 5 \\
Minimum & 2 & 2 & 1.666667 \\
Std. Dev. & 0.469955 & 0.515411 & 0.424487 \\
Skewness & -1.779237 & -1.441268 & -1.828071 \\
Kurtosis & 8.37575 & 6.035723 & 9.825113 \\
Jauque-Bera & 479.6881 & 202.2635 & 691.9177 \\
Probability & 0 & 0 & 0 \\
\hline
\end{tabular}

Source: Authors (2015).

Table 5. Correlation coefficients matrix.

\begin{tabular}{cccc}
\hline & TCOMP & TKNOW & TPEN \\
\hline TCOMP & 1.0000 & $0.6534^{*}$ & $0.8317^{*}$ \\
TKNOW & $0.6534^{*}$ & 1.0000 & \\
TPEN & $0.8317^{*}$ & 0.4536 & 1.0000 \\
\hline
\end{tabular}

Source: Authors (2015); ${ }^{*}$ significant at 5\% level.

Table 6. Results of OLS regression.

\begin{tabular}{ccccc}
\hline Variable & Coefficient & Std. Error & t-statistics & prob. \\
C & 1.768721 & 0.254231 & 6.957148 & 0.0000 \\
TKNOW & 0.460597 & 0.051900 & 8.874789 & 0.0000 \\
TPEN & 0.115214 & 0.063016 & 1.828318 & 0.0686 \\
R-squared & 0.316421 & & & \\
Adjusted R-squared & 0.311432 & & & \\
F-statistic & 63.41589 & & & \\
Prob (F-statistic) & 0.00000 & & & \\
Durbin-Watson stat & 1.79777 & & & \\
\hline
\end{tabular}

Source: Authors (2015).

resulting from low level of tax knowledge.

We recommend that the government should consider seriously the characteristics of non compliance taxpayers; review current regulations and possibly as a result, increase awareness of the importance of tax and penalty (enforcement). Also, government should attempt to build good relationship with small and medium enterprise taxpayers in seeking to improve general tax compliance level as well as total tax revenue. Government should therefore do everything possible to increase public knowledge on tax matters and tax education should be included in school curricula at all times. Small and medium scale business owners should also seek to advance their tax knowledge and awareness for the mutual benefits of the governments and taxpayers.

\section{References}

[1] Bautigam, D., Fjeldstad, O.H. and Moore, M. (2005) Taxation and State-Building in Developing Countries: Capacity and Consent. Cambridge University Press, Cambridge, 1-33. 
[2] Internal Revenues Services (IRS) (2009) Update on Reducing the Federal Tax Gap and Improving Voluntary Compliance. http://www.irs.gov/pub/newsroom/tax_gap_report_final_version.pdf

[3] Andreoni, J., Erard, B. and Feinstein, J. (1998) Tax Compliance. Journal of Economic Literature, 36, 818-860.

[4] Singh, V. and Bhupalan, R. (2001) The Malaysian Self Assessment System of Taxation: Issues and Challenges. Tax National, 12-17.

[5] Bahl, R. and Bird, R. (2008) Tax Policy in Developing Countries: Looking back and forward. National Tax Journal, 297-301. http://dx.doi.org/10.17310/ntj.2008.2.06

[6] James, S. and Alley, C. (2004) Tax Compliance, Self Assessment and Tax Administration. Journal of Financial and Management in Public Services, 2, 27-42.

[7] Masato, A. (2009) Globalization of Production and the Competitiveness of Small and Medium-sized Enterprises in Asia and the Pacific: Trends and Prospects. Publication of United Nations Economic and Social Commission for Asia and the Pacific (ESCAP), Studies in Trade and Investment Series, 1-31.

[8] Farzbod, J. (2000) Investigation of the Effective Factors in the Tax Efficiency. M.Sc. Thesis, Governmental Management Training Centre, Tehran.

[9] Lumumba, O.M., Migwi, S.W. and Magutu, O. (2010) Taxpayers’ Attitudes and Tax Compliance Behavior in Kenya: How the Taxpayers' Attitudes Influence Compliance Behavior among SMEs Business Income Earners. African Journal of Business \& Management, 1, 112-122.

[10] Weichenrieder, A.J. (2007) Survey on the Taxation of Small and Medium-sized Enterprises. Draft Report on Responses to the Questionnaire. http://www.oecd.org/dataoecd/52/25/39597756.pdf

[11] Hasseldine, J., Holland, K. and Rijt, P.V. (2009) The Management of Tax Knowledge. The Association of Chartered Certified Accountants, ACCA, London. www.accaglobal.com

[12] Csontos, L., Kornai, J. and Tóth, I.G. (1998) Tax Awareness and Reform of the Welfare State: Results of a Hungarian Survey. Economics of Transition, 6, 287-312. http://dx.doi.org/10.1111/j.1468-0351.1998.tb00050.x

[13] Chattopadhyay, S. and Das-Gupta, A. (2002) The Compliance Cost of the Personal Income Tax and Its Determinants. Report to the National Institute of Public Finance and Policy, New Delhi.

[14] Loo, E.C. and Ho, J.K. (2005) Competency of Malaysian Salaried Individuals in Relation to Tax Compliance under Self Assessment. Journal of Tax Research, 3, 45-62.

[15] Mohani, A. (2001) Personal Income Tax Noncompliance in Malaysia. PhD Thesis, Victoria University, Melbourne.

[16] Saira, K., Zariyawati, M.A. and Yoke-May, L. (2010) An Exploratory Study of Goods and Services Tax Awareness in Malaysia. Seminar on National Resilience (SNAR), Political Management and Policies in Malaysia, Langkawi, 13-15 July 2010, 265-276. http://repo.uum.edu.my/3178/1/S14.pdf

[17] Richardson, G. (2006) Determinants of Tax Evasion: A Cross Country Investigation. Journal of International Accounting, Auditing and Taxation, 15, 150-169. http://dx.doi.org/10.1016/j.intaccaudtax.2006.08.005

[18] Braithwaite, V. (2007) Taxation and Good Governance. University House Lecture and House Dinner Series, Australian National University, Canberra. www.vab.anu.edu.au/present/taxunihouse.pdf

[19] Palil, M.R. (2010) Tax Knowledge and Tax Compliance Determinants in Self Assessment System in Malaysia. PhD Thesis, University of Birmingham, Birmingham.

[20] Yan, M.C.K., Arokiasamy, L. and Suat, C.L.A. (2010) Indirect Taxation: Awareness and Impact on Undergraduates. International Research Journal of Finance and Economics, No. 41, 43-50. www.eurojournals.com/finance.htm

[21] Palil, M.R. and Mustapha, A.F. (2011) Tax Audit and Tax Compliance in Asia: A Case Study of Malaysia. European Journal of Social Sciences, 24, 7-32.

[22] Saad, N. (2012) Perception of Tax Fairness and Tax Compliance Behavior: A Comparative Study. Jurnal Pengurusan, 36, 89-100.

[23] Mukasa, J. (2011) Tax Knowledge, Perceived Tax Fairness and Tax Compliance in Uganda. Master of Science, Makerere University, Kampala.

[24] Lai, M.L, Zalilawati, Y., Amran, M.M. and Choong, K.F. (2013) Quest for Tax Education in Nonacounting Curriculum: A Malaysia Study. Asian Social Science, 9, 154-162. http://dx.doi.org/10.5539/ass.v9n2p154

[25] Allingham, M.G. and Sandmo, A. (1972) Income Tax Evasion: A Theoretical Analysis. Journal of Public Economics, 1, 323-338. http://dx.doi.org/10.1016/0047-2727(72)90010-2

[26] Doran, M. (2009) Tax Penalties and Tax Compliance: A Personal Income Tax Non-Compliance in Malaysia. PhD Thesis, Victoria University, Melbourne.

[27] Oluchi, M. (2012) PITA 2011: Key Benefits to Taxpayers and the Economy. Guage.

[28] FIRS (2013) Self Assessment First Guide. 
[29] Internal Revenues Board (IRB) (2000) Self Assessment System: IRB Guide on Tax Audit.

[30] Virmani, A. (1989) Indirect Tax Evasion and Production Efficiency. Journal of Public Economics, 39, 223-237. http://dx.doi.org/10.1016/0047-2727(89)90041-8

[31] Namusonge, G.S., Biraori, O.E. and Kipicoech, E.C. (2014) Factors Affecting Tax Compliance among Small and Medium Enterprises in Kitale, Kenyan. International Journal of Recent Research in Commerce Economics \& Management, 1, 60-75.

[32] Kirchler, E. (2007) The Economic Psychology of Tax Behavior. Cambridge University Press, Cambridge. http://dx.doi.org/10.1017/CBO9780511628238

[33] Wang, L. and Conant, J. (1988) Corporate Tax Evasion and Output Decision of the Uncertain Monopolist. National Tax Journal, 41, 579-581.

[34] Gordon, J. (1990) Evading Taxes by Selling for Cash. Oxford Economic Papers, 42, 244-255.

[35] Marrelli, M. and Martina, R. (1998) Tax Evasion and Strategic Behavior of the Firm. Journal of Public Economics, 37, 55-69. http://dx.doi.org/10.1016/0047-2727(88)90004-7

[36] Alm, J., Jackson, B. and McKee, M. (1992) Institutional Uncertainty and Taxpayer Compliance. American Economic Review, 82, 18-26.

[37] Feld, L.P. and Frey, B.S. (2007) Tax Compliance as the Result of a Psychological Tax Contract: The Role of Incentives and Responsive Regulation. Law and Policy, 29, 102-120. http://dx.doi.org/10.1111/j.1467-9930.2007.00248.x

[38] Riahi-Belkaoui, A. (2004) Relationship between Tax Compliance Internationally and Selected Determinants of Tax Morale. Journal of International Accounting, Auditing and Taxation, 13, 135-143. http://dx.doi.org/10.1016/j.intaccaudtax.2004.09.001

[39] Fakile, A.S. (2011) Analysis of Tax Morale and Tax Compliance in Nigeria. PhD Thesis, Covenant University, Otta. 